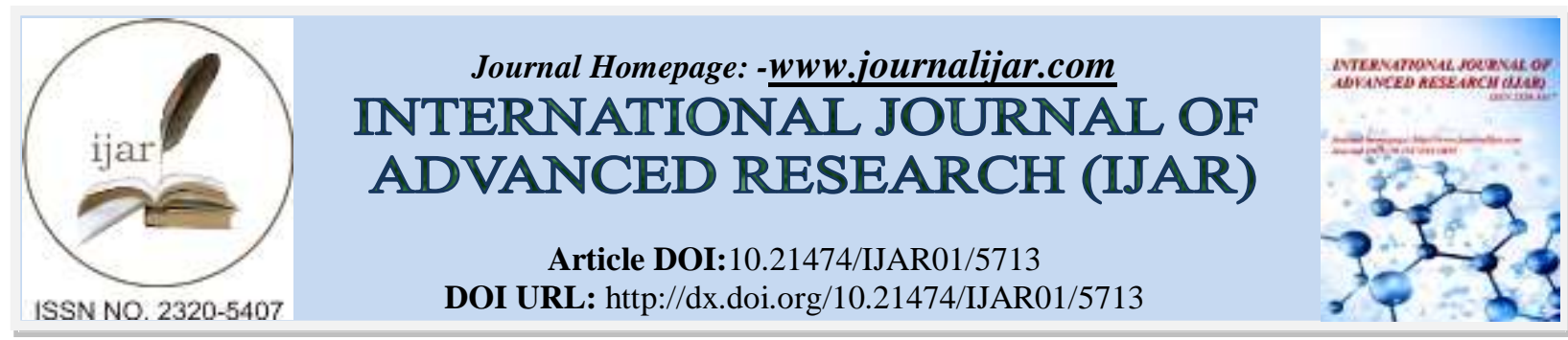

RESEARCH ARTICLE

\title{
A CASE STUDY ON THE THERAPEUTIC EFFECT OF MALLA SINDOOR AND SHRING BHASMA IN THE ELEVATED ABSOLUTE EOSINOPHIL COUNT.
}

\begin{abstract}
Bharati P.L. ${ }^{1}$, Agarwal Prateek ${ }^{2}$, Sharma Rashmi ${ }^{3}$, Subhose V. ${ }^{4}$ and Jadhav A. D .
1. Research Officer (S-2) Regional Ayurveda Research Institute for Drug Development, Aamkho, Gwalior (M.P.).

2. Research Officer-Ay Regional Ayurveda Research Institute for Drug Development, Aamkho, Gwalior (M.P.).

3. Senior Consultant Regional Ayurveda Research Institute for Drug Development, Aamkho, Gwalior (M.P.).

4. Assistant Director, Regional Ayurveda Research Institute for Drug Development, Aamkho, Gwalior (M.P.).

5. Ex-Assistant Director Regional Ayurveda Research Institute for Drug Development, Aamkho, Gwalior (M.P.).
\end{abstract}

\section{Manuscript Info}

\section{Manuscript History}

Received: 24 August 2017

Final Accepted: 26 September 2017

Published: October 2017

Key words:-

Allergic Rhinitis, Absolute Eosinophil Count, Bronchial hyper reactivity, VataKaphajaPratishyay,MallaSindoor, ShringBhasma.

\section{Abstract}

Background: Allergic rhinitis is one of the most common chronic conditions with a significant impact on the quality of life. The association between eosinophils and allergic disease has been known for many years. Allergic rhinitis patients are at risk of development of Asthma. The patients may also have peripheral eosinophilia and bronchial hyper reactivity. Absolute eosinophil count was correlated with bronchial hyper reactivity. As per Ayurveda, allergic rhinitis is compared with Vata-KaphajaPratishyay. The concept of Ama, Asatamya and ViruddhAahara also predict the allergic conditions.

Aims \& Objectives:To evaluate the therapeutic effect of MallaSindoorand ShringBhasmain the elevated absolute eosinophil count

Materials and Methods: In the present study a 71 year old women presented with clinical features indicative of Allergic rhinitis were examined; a clinical diagnosis was made in the OPD of Regional Ayurveda Research Institute for Drug Development (RARIDD) Gwalior and then confirmed with the help of X-ray and pathological examination. After confirmation of allergic rhinitis on basis of increased absolute eosinophil count, patient was considered for this case study. This case of allergic rhinitis with elevated absolute eosinophil count was managed by Ayurvedic Intervention of MallaSindoor $125 \mathrm{mg}$ and ShringBhasma $250 \mathrm{mg}$ thrice a day with Honey for 17 days at the outpatient department level.

Result: The response of the treatment was found highly significant by symptomatic and pathological investigation. At the end of treatment period of 17 days as compared with baseline, a significant change in clinical symptoms was observed and significant reduction in AEC.

Conclusion: MallaSindoor and ShringBhasmaadministered together in above-mentioned dose were found very effective and safe in patient of allergic rhinitis with increased absolute eosinophil count. 


\section{Introduction:-}

Allergic rhinitis patients are at risk of development of Asthma. These patients will have Bronchial hyper reactivity ${ }^{1}$. Bronchial hyper reactivity (BHR), one of the hallmarks of Bronchial Asthma, is a risk factor for the development of Asthma ${ }^{2,3}$. In non-atopic Asthma a relationship between the peripheral blood eosinophil count and the FEV1 has been observed and the Eosinophil count is considered useful in monitoring disease activity ${ }^{4}$. Various studies have attempted correlating Nasal Smear Eosinophilia (NSE) and Absolute Eosinophil Count (AEC) in peripheral blood in patients of allergic rhinitis, though very little is known about correlation of symptoms and severity of clinical score with NSE and peripheral blood AEC ${ }^{5}$.

Allergic rhinitis is seasonal or perennial. With an appropriate history and detailed examination, the diagnosis is usually not problematic. However, it is found that the common symptomatology of rhinitis congestion, sneezing, nasal itching, and rhinorrhea show significant overlap with non-allergic rhinitis (NAR) ${ }^{6}$. Treatment with inhaled sodium cromoglycate produces a small reduction in bronchial hyper reactivity ${ }^{7}$. Remission of bronchial hyper reactivity occurred more frequently in subjects treated with intranasal corticosteroids ${ }^{8,9,10}$.

As per Ayurvedic context, Allergic rhinitis is compared with Vata- KaphajaPratishyay. The concept of Aama, Asatamya and ViruddhAahara also predict the allergic conditions. Ama is the product of impaired digestion and metabolism. It affects Rasa and RaktaDhatu leading to manifestation of Pratishyaya. Wrong food combinations (Viruddhaahara) having antagonist properties like fish with milk, fruit juice with milk, clarified butter with honey, ice cream after night meals, etc. leads to allergy ${ }^{11}$.

MallaSindoor is one of such medicament indicated mainly in diseases such as Shwasa, Kasa(respiratory disorders), and is thought to be an effective drug in combating Vedanaand Vatarogaharaproperty ${ }^{12}$.

Shringbhasma is used in Ayurvedic medicine for treating Hikka (Hiccup), Kasa (cough), Swasa (difficult breathing including asthma), Hrtsula (cardiac colic), Urastoya and Parshvashoola (abdominal distension and intestinal rumbling) ${ }^{13,14}$.

\section{Aim And Objective:-}

To evaluate the therapeutic effect of MallaSindoorand ShringBhasmain the elevated Absolute Eosinophil Count

\section{Material and Methods:-}

The patient presented with clinical features indicative of allergic rhinitis was examined; a clinical diagnosis was made in the OPD of Regional Ayurveda Research Institute for Drug Development (RARIDD) Gwalior and then confirmed with the help of X-ray and pathological examination. After confirmation, patient having allergic rhinitis with increased Absolute Eosinophil Countwere considered for this case report. The demographic profile, associated allergic rhinitis symptoms such as rhinitis congestion, sneezing, nasal itching, dyspnoea and rhinorrhea were noted. Laboratory investigations like blood and radiological report were also documented. Purpose and effect of the Ayurvedic medicines were explained to the patient. MallaSindoorand ShringBhasmawere prescribed to the patient willing for medication. Patient outcomes were also analyzed.

\section{Study Design:-}

MallaSindoor $125 \mathrm{mg}$ and ShringBhasma250 mg were prescribed to take orally thrice a day with honey for the duration of 2-3 weeks to the patient.

\section{Case Report:-}

A 71 years old female having complaints of breathlessness, chest pain, cough, indigestion and weakness since 1 year. She had taken some modern medical treatment for the same problem and did not get relief for the same. She was interested to take Ayurvedic treatment for the same problem. Patient visited OPD of Regional Ayurveda Research Institute for Drug Development (RARIDD), Gwalior on $9^{\text {th }}$ Dec. 2016 vide registration no 3494. Initially some Ayurvedic medicines like Sitopaladichurna, Nardiyalaxmivilasras, Chandramritras, Swaskutharras, Haridrakhanda, Kanchnarguggulu etc. were prescribed. She was advised for CBC, ESR, RBS and X-ray chest PA view. Blood report shown normal values but X-ray report showed Pneumonitis in bilateral mid and lower lung zone. Same treatment was given for 15 days and observed her complaints but prescribed medicines were not responded significantly. 
Absolute Eosinophil Count was advised to the patient and report was 1.32 thou $/ \mathrm{mm}^{3}$ (Normal 0.02-0.50 thou/ $\mathrm{mm}^{3}$ ). As per report above medicines were stopped and new prescription consisting of MallaSindoor $125 \mathrm{mg}$ and ShringBhasma $250 \mathrm{mg}$ were given to take orally thrice a day with honey for 10 days to the patient. Patient purchased the medicines from local chemist shop as per prescription. After 10 days patient reported with significant relief in breathlessness, chest pain, cough and indigestion. The medicines were further continued for 7 days. Patient reported 95\% relief in her complaints due to treatment by MallaSindoor and ShringBhasma. After follow up repeat Absolute Eosinophil Count was done and report was found to be in normal range $\left(0.50 \mathrm{thou} / \mathrm{mm}^{3}\right)$.

\section{Discussion:-}

The present study showed the relationship between peripheral blood eosinophilia and bronchial hyper reactivity in allergic rhinitis and also revealed a strong association between allergic rhinitis and lower airway dysfunction. Allergic rhinitis is a frequent inflammatory chronic disease induced by an IgE-mediated reaction after allergen exposure in the nasal mucosa. It is now clear from a large number of cross-sectional studies that allergic rhinitis is strongly associated with Asthma and $\mathrm{BHR}^{15}$. The mean value of blood AEC was below the standard normal value with 307.6 in patients having only nasal symptoms and 460 in patients having nasal with respiratory symptoms. Hence, blood AEC tends to be more in the respiratory system ${ }^{5}$. Similar finding was observed by Jagdeeshwaret al. ${ }^{16}$ but with a little highervalue of AEC which was 416.26 in patients having only nasal symptoms and 683.76 in patients having nasal and respiratory systems.

Malla-Sindoor is a mineral formulation of Ayurveda and contains Malla means Arsenic Trioxide $\left(\operatorname{As}_{2} \mathrm{O}_{3}\right.$ ), Paradmeans Mercury (Hg) and Gandhak means Sulphur (S). Arsenic is a strong poison and in Ayurvedic medicines it is used only after proper detoxification. Malla-Sindoor is a KanthasthaKupipakvaRasayana(a preparation in which product is obtained at the neck of glass bottle). For the preparation of Kupipakwarasayan, preparation of Kajjali, time duration, and heating pattern are the most important factors to obtain maximum quantity of yield and to increase the efficacy of the product without any untoward effect ${ }^{12}$.

The quality of MallaSindoor is Ushna, Tikshna, Kapha-Amasanshodhana. It is stimulant to lungs, heart and nerves. This stimulant action may facilitate more supply of oxygenated blood to lungs. Malla and Raskarpur, ingredients of Malla-Sindoor have purgative properties. Thus it also relieves the Malabaddhata (Constipation) which is line of treatment of asthma. As it is Arseno-Mercurial preparation, it has antibacterial and antiviral property also. Hence it may useful in infection originated diseases ${ }^{17}$.

MallaSindoor is useful in Vata and Kapha diseases. It gives good result in treatment of Vata diseases, Pakshaghata (Hemiplegia), Amavata (Rheumatism), Gout and Kapha diseases, Pneumonia, Respiratory illness. MallaSindoor is also indicated in Hysteria, Weakness in old age, Chronic Asthma, Indigestion, Weakness of male sex organ, Influenza, Vishamjwar, Prameha ${ }^{18}$.

ShringaBhasma is an Ayurvedic medicine prescribed mainly for asthma.ShringaBhasma is aodourless dull white powder with chalk like taste. Qualitative inorganic analysis showed the presence of Carbonates, Sulphates, Chlorides, Potassium, Calcium and Magnesium. The organic contents like tannins and proteins were also identified $^{19}$.

ShringaBhasma is used in respiratory disorders accompanied with a productive cough, wheezing, chest congestion, chest tightness, chest pain and fever. ShringaBhasma helps clearing the lungs and airways. It is used when there is a need to regulate mucous secretion. ShringaBhasma has bacteriostatic action, which most likely to appear in tuberculosis. It inhibits the growth of Mycobacterium tubercle. Though, ShringaBhasma plays a supportive role in Tuberculosis and the main medicine is Swarna Bhasma. ${ }^{20,21}$

Ushna, Tikshna, Kapha-Amasanshodhana, purgative, stimulant, antibacterial and antiviral properties of MallaSindoor and kaphaghna, soothing, bacteriostatic properties of ShringBhasma might have reduced elevated Absolute Eosinophil Count in patient and provided relief from the sign \& symptoms of allergic rhinitis.

\section{Conclusion:-}

MallaSindoor $125 \mathrm{mg}$ and ShringBhasma, $250 \mathrm{mg}$ administered together orally with honey thrice a day provided relief in sign and symptoms of patient of allergic rhinitis with increased absolute eosinophil count. The treatment 
was found very effective and safe. The findings of this case report may be helpful for treatment of allergic rhinitis with increased absolute eosinophil count and the effect of the drugs may be further confirmed in clinical study employing more number of patients of allergic rhinitis with increased absolute eosinophil count.

\section{Acknowledgement:-}

The Author expresses sincere thanks to the Director General, Deputy Director General Technical, CCRAS, New Delhi for providing Technical support. I am very thankful to the In-charge of Regional Ayurveda Research Institute for Drug Development (RARIDD) Gwalior for their best co-operation.

\section{References:-}

1. Dr.AjithKumar.C.S Predictive value of absolute Eosinophil count for Bronchial Hyper reactivity in allergic rhinitis: Indian Journal of Basic \& Applied Medical Research; March 2013: Issue-6, Vol.-2, P. 623-628

2. Brutsche MH, Downs SH, Schindler C, GerbaseMW,Schwartz J, Frey M, Russi EW, Ackermann-Liebrich U, Leuenberger P. Bronchial hyperresponsiveness and the development of asthma and COPD in asymptomatic individuals: SAPALDIA cohort study. Thorax 2006;61:671-677.

3. Xu X, Rijcken B, Schouten JP, Weiss ST. Airways responsiveness and development and remission of chronic respiratory symptoms in adults. Lancet 1997;350:1431-1434.

4. Horn BR, Robin ED, Theodore J, Van Kessel A. Total eosinophil counts in the management of bronchial asthma. N EngI J Med 1975;292:1152-5.

5. Anand K. Patel, Tapan P. NagpalComparison of blood absolute eosinophil count and nasal smear eosinophils with symptoms and severity of clinical score in patients of allergic rhinitis : Indian Journal of Allergy, Asthma and Immunology $\mid$ Jul-Dec $2014 \cdot$ Volume 28 - Issue 2

6. Bachert C. Persistent rhinitis - Allergic or non allergic? Allergy 2004;59:11-5.

7. Rocchiccioli K, Pickering CAC, Cole M, HorsfieldN.Effect of regular treatment with sodium cromoglycateon non-specific bronchial hyperreactivity [Abstract].Thorax 1984;39:706.

8. Aubier M, Levy J, Clerici C, Neukirch F, Herman D. Different effects of nasal and bronchial

9. glucocorticosteroid administration on bronchial hyperresponsiveness in patients with allergic rhinitis. Am Rev Respir Dis 1992;146:122-126

10. Corren J, Adinoff AD, Buchmeier AD, Irvin CG. Nasal beclomethasone prevents the seasonal increase in bronchial responsiveness in patients with allergic rhinitis and asthma. J Allergy ClinImmunol 1992;90:250-256.

11. Watson WT, Becker AB, Simons FE. Treatment of allergic rhinitis with intranasal corticosteroids in patients with mild asthma: effect on lower airway responsiveness. J Allergy ClinImmunol 1993;91:97-101.

12. Allergic Rhinitis: Causes, Remedies, Ayurvedic treatment, Herbs: available from http://easyayurveda.com/2016/03/05/allergic-rhinitis-remedies-ayurvedic-treatment-herbs/

13. Vivek Kumar, B. J. Patgiri, P. K. Prajapati, GalibRuknuddin, Standard manufacturing procedure of MallaSindura: International Journal of Green Pharmacy, Oct-Dec 2016: 10 (4) 235

14. Anonymous, the Ayurvedic Formulary of India, Part -I, First edition, Ministry of Health and family Planning, Government of Indian, New Delhi, 1978.

15. Swami SadasivaTirta, the ayurvedicEncyclopaedia, First Edition, Indian Books Centre, New Delhi, 1998.

16. Bousquet J, Van Cauwenberge P, Khaltaev N. Allergic rhinitis and its impact on asthma. J Allergy ClinImmunol 2001;108:S147-S334.

17. Jagdeeshwar K, Venumadhav V, Chowdary S, Sudharani V, Kumar V. A study on serum IgE levels, peripheral eosinophils and individual symptoms in patients with non infective rhinitis and asthma and related conditions. Int J Pharm PharmSci 2012;4:88-92.

18. AmitNaphade, GurucharanBhuyan, PSC Murty: A Clinical study to Assess the efficacy of Malla-Sindoor for the Management of Pakshaghat (Hemiplagia) JRAS Vol. XXXII, No. 3-4, July-Dec. 11, pp 67-78.

19. Anupama, MallaSindoor Benefits, Ingredients, Dosage: available from https://www.bimbima.com/ayurveda/malla-sindoor-benefits-ingredients-dosage/432/ September 18, 2014.

20. A. Rajasekaran, S. Murugesan: Stansardisation of SringaBhasma, Ancient Science of Life Vol.No. XXI (3) January 2002 ,pp 167-169

21. Dr.Jagdev Singh ShringBhasma, Ayur times available from https://www.ayurtimes.com/shringa-bhasma/ Updated April 11, 2017. 